\title{
Three-dimensionally preserved digestive systems of two Cambrian hyolithides (Hyolitha)
}

\author{
HAIJING SUN, LOREN E. BABCOCK, JIN PENG \& YUANLONG ZHAO
}

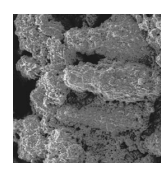

\begin{abstract}
Hyoliths are a group of Paleozoic marine bilaterian animals with conical aragonitic shells. Evolution of the hyoliths, and their relationships to other early bilaterians, are controversial. New exceptionally preserved hyolithide hyolith specimens from Cambrian Stage 4 strata of Nevada, USA, and Guizhou, China, provide information on the internal soft-part anatomy that is pertinent to understanding the early evolutionary history of the group. Two specimens show partial digestive tracts preserved in three dimensions. The guts comprise a modified U-shaped system consisting of a spiral intestine wound about a nearly straight tube. Similarity to the spiral U-shaped gut tract of sipunculans supports an inferred sister-group relationship between sipunculans and hyoliths. - Key words: Hyolitha, Hyolithida, gut tract, Cambrian, Nevada, China.
\end{abstract}

Sun, H., BABCOCK, L.E., PENG, J. \& ZHAO, Y. 2016. Three-dimensionally preserved digestive systems of two Cambrian hyolithides (Hyolitha). Bulletin of Geosciences 91(1), 51-56 (3 figures). Czech Geological Survey, Prague. ISSN 1214-1119. Manuscript received September 30, 2015; accepted in revised form November 5, 2015; published online December 21, 2015; issued March 17, 2016.

Haijing Sun, Resources and Environmental Engineering College, Guizhou University, 550025 Guiyang, China, and State Key Laboratory of Palaeobiology and Stratigraphy, Nanjing Institute of Geology and Palaeontology, Chinese Academy of Sciences, 210008 Nanjing, China; hjsun1987@163.com • Loren E. Babcock, School of Earth Sciences, The Ohio State University, Columbus, Ohio 43210, USA; babcockloren@gmail.com・Jin Peng (corresponding author) \& Yuanlong Zhao, Resources and Environmental Engineering College, Guizhou University, 550025 Guiyang, China; gzpengjin@126.com,zhaoyuanlong@126.com

One of the fossil groups most emblematic of rapid evolutionary experimentation during the early part of the Cambrian Period is the hyoliths, a group of bilaterian marine animals that had conical aragonitic shells. They appeared early in the Cambrian Period, became one of the most numerous and diverse of biomineralizing animals during that time, and ranged through the Paleozoic before becoming extinct. More than 150 hyolith genera (Qian \& Xiao 1995) and hundreds of species have been named. Hyoliths consist of two subgroups, orthothecides and hyolithides, which are usually treated as orders (e.g. Marek 1967, Runnegar et al. 1975, Marek \& Yochelson 1976, Pojeta 1987, Malinky \& Yochelson 2007). Evolution of these two groups and their relationships to other early bilaterians, have been discussed extensively in literature. A consensus has emerged that hyoliths share an evolutionary relationship with mollusks but the closeness of that relationship and taxonomic expression of it are subject to interpretation (Pojeta 1987). Gross anatomy of the digestive tract has been used to provide some of the strongest evidence of the evolutionary relationships of hyoliths. Configuration of the guts, notably of the orthothecide hyoliths, previously has been used to infer that hyoliths share a closer affinity with sipunculans than with mollusks (e.g. Runnegar et al. 1975, Runnegar 1980, Pojeta 1987).

Digestive systems of hyoliths are now known from both orthothecide and hyolithide hyoliths. They have been preserved in part by sediment fill and partly through mineralization (silicification, phosphatization, or pyritization) or carbonization. The configuration of the digestive tract of orthothecides is now well established from good three-dimensional material (Thoral 1935, Marek 1967, Runnegar et al. 1975, Meshkova \& Sysoyev 1981, Pojeta 1987, Kruse 1997, Horný 1998, Malinky 2003, Wilson \& Ratcliffe 2003, Valent \& Kraft 2009, Devaere et al. 2014). Most published reconstructions of the internal anatomy of hyolithides preceded the discovery of hyolithide soft-parts and were based on orthothecide anatomy (Marek \& Yochelson 1976, Dzik 1980, Missarzhevskiy 1989). Until the present report, hyolithide guts were known only from well-preserved specimens compressed in shale (Babcock \& Robison 1988, Mao et al. 1992, Butterfield 2003, English \& Babcock 2010, Botting et al. 2015, Robison et al. 2015).

Here we report new internal anatomical information from two exceptionally preserved hyolithide hyoliths collected from Cambrian Stage 4 (Series 2) strata of Nevada, 
USA, and Guizhou, China (Fig. 1). The specimens show partial gut tracts preserved in three dimensions. The new specimens confirm the general structure inferred from previously described compressed material, but show details heretofore unknown, including a form of spiral gut tract that appears to be distinct among animals. These specimens show a highly modified U-type gut configuration that consists of a spiral portion wound about a slightly curving tube. Structure of the digestive system of hyolithides lend supports to the view that hyoliths in general are a lophotrochozoan phylum having a closer evolutionary affinity with sipunculans than with mollusks.

\section{Material and methods}

New hyolithid specimens (Fig. 1) preserving fossilized gut tracts are from two Cambrian localities: 1, grey-green shale of the basal Emigrant Formation (Amecephalus arrojosensis Zone; provisional Stage 4), Split Mountain section, Nevada, USA; and grey-green shale of the Balang Formation (Arthricocephalus chauveaui Zone; provisional Stage 4), Wenglingtang section, Guizhou, China. These localities have yielded one specimen each showing three-dimensionally preserved digestive tracts. Illustrated specimens showing internal soft parts are split open along natural bedding planes. Without key external features well exposed, the specimens cannot be confidently identified to genus or species levels.

Specimens were examined and imaged using standard light microscopy, an FEI Quanta 250 Field Emission Gun Scanning Electron Microscope (SEM) with Electron Dispersive X-ray (EDX), a Neurologica CereTom CT scanner, and digital macrophotography [Canon Rebel Xsi (450D) with a Canon $60 \mathrm{~mm}$ f/2,8 Macro USM lens]. Digital macrophotographs were stacked and rendered using Photoshop and CorelDraw software.

Specimens are reposited in the Paleontological Research Institution, Museum of the Earth, Ithaca, New York, USA (PRI); and the paleontological collection of Guizhou University $(\mathrm{KW})$.

\section{Hyolithid anatomy and new information}

Two groups of hyoliths, usually classified as orders, are recognized: Orthothecida and Hyolithida. Orthothecides have relatively simple conchs characterized by planar growth increments leading to a planar aperture and a retractable planar operculum; they usually have a pair of bladelike or cylindrical cardinal processes on the internal surface of the operculum (e.g. Marek 1966, 1967; Skovsted et al. 2004, 2014). Hyolithides have conchs characterized by biplanar growth increments leading to a biplanar aperture including a protruding ligula; they also have both cardinal processes and one or more pairs of clavicles on the interior of the operculum, plus a pair of slender helens (e.g. Marek 1963, 1966, 1967).

Based on an orthothecide model, hyolithide soft parts have usually been reconstructed to include a ribbon-like, ventrally disposed, intestine looping left to right in a single plane, followed by a nearly straight dorsal rectum (Fig. 2A). Illustrations of hyolithide digestive tracts that have been compressed in shale (Babcock \& Robison 1988, Mao et al. 1992, Butterfield 2003, English \& Babcock 2010, Robison et al. 2015) tended to confirm that the gut had folded and nearly straight sections but were ambiguous as to the precise configuration of these parts within a three-dimensional conch.

New specimens from Nevada and Guizhou (Fig. 1) reveal the hyolithide gut to have a modified U-shape configuration. Both specimens preserve incomplete digestive tracts by means of sediment filling and iron oxide (possibly after pyrite). Most of the preserved parts are in the apical end of the conch, so the configuration of organs in other areas of the conch is less certain. However, it can be inferred from good illustrations of compressed material showing more complete digestive tracts (Babcock \& Robison 1988, Mao et al. 1992, Butterfield 2003, English \& Babcock 2010) that the pattern established apically continues to approximately the position of the aperture. The specimens show a slender tube, presumably the intestine, wound in a tight spiral around a simple, nearly straight, subcentral tube of wider diameter, presumably the rectum. In the specimen from Nevada, the end of the larger tube emerges near the aperture (Fig. 1C), at or close to the inferred position of the anus. Evidence from this specimen, combined with previously illustrated material (Babcock \& Robison 1988, Mao et al. 1992, Butterfield 2003, English \& Babcock 2010, Robison et al. 2015) indicates that the rectum extends much of the length of the conch.

The new specimens provide information for a new reconstruction of the hyolithide interior (Fig. 2B-D), and for further information about hyolithide ecology. The entire gut system occupies a relatively narrow area, providing large areas in the lateral sides of the triangular shell for muscles, mantle tissue, feeding devices, and even retraction of the biomineralized helens. Helens are important functional devices for hyolithides (e.g. Marek 1963; Runnegar et al. 1975; Babcock \& Robison 1988; Martí Mus \& Bergström 2005, 2007; Martí Mus et al. 2014), but the manner of their retraction and extension (Babcock \& Robison 1988, Butterfield \& Nicholas 1996, Marek et al. 1997, Martí Mus \& Bergström 2007; herein Fig. 2C, D) has remained obscure, as muscle attachment structures were incompletely known until recently. Martí Mus et al. (2014) identified possible muscle attachment sites on the proximal ends of the helens that may have functioned in retraction of 
Haijing Sun et al. • Three-dimensionally preserved digestive systems of two Cambrian hyolithides

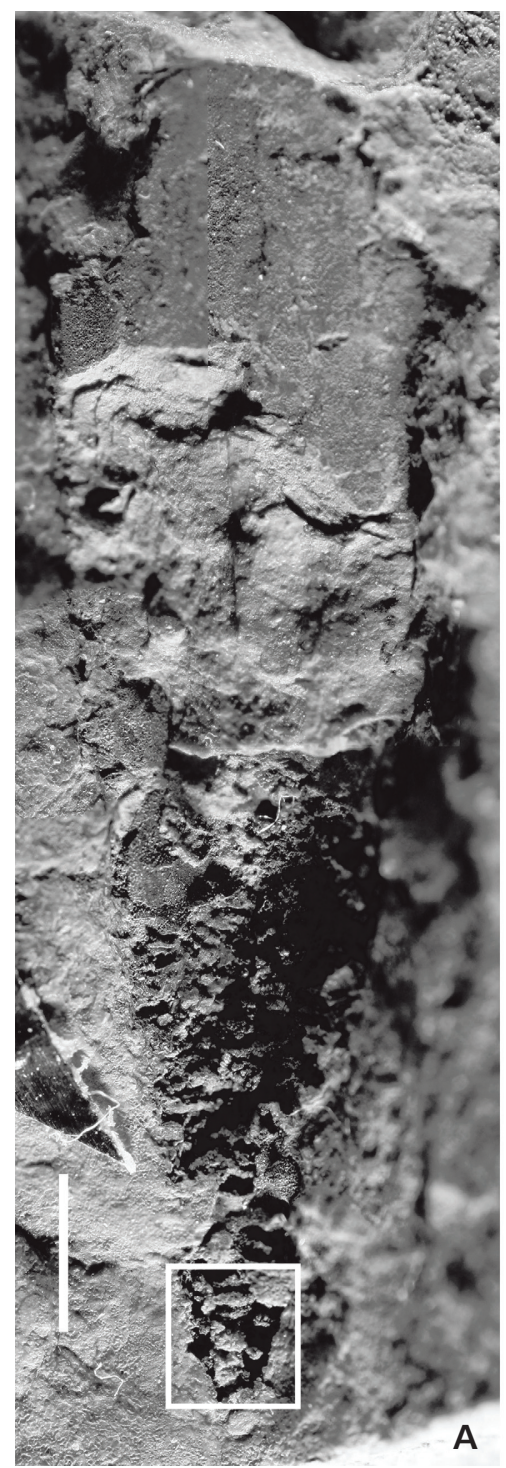

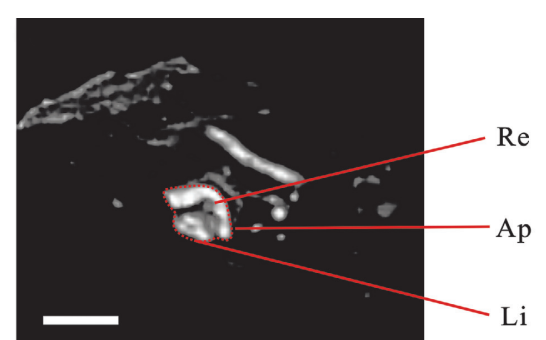

C

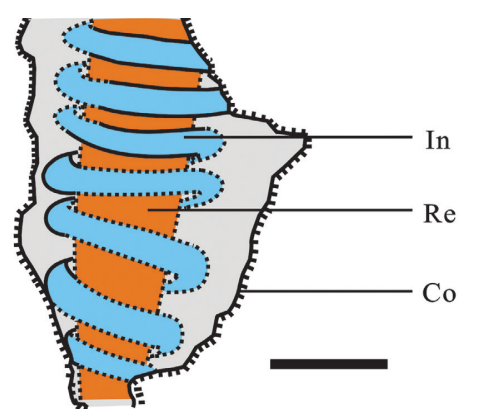

\section{B}
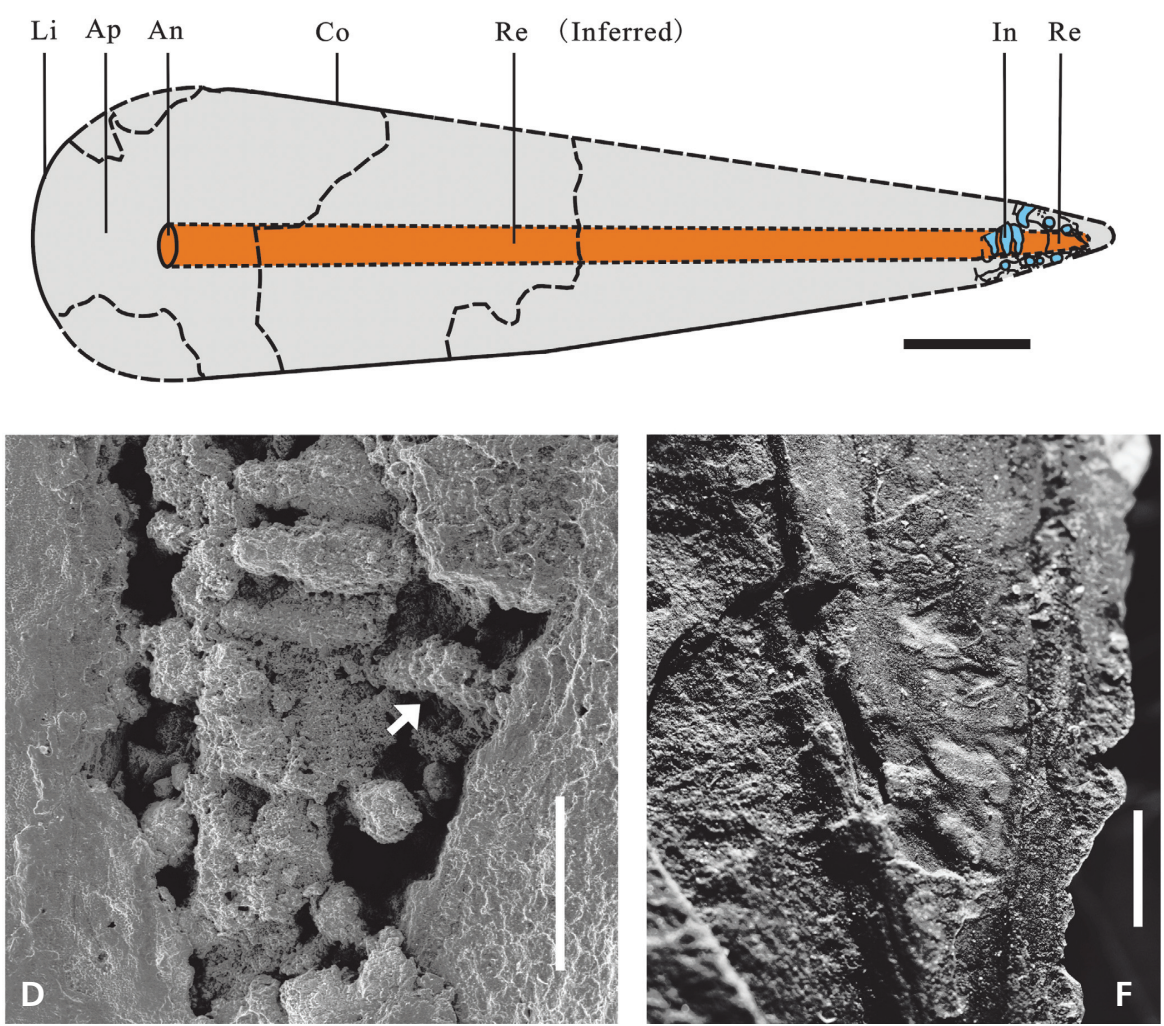

Figure 1. Hyolithide specimens with preserved gut tracts. • A-E - undetermined hyolithide from the Emigrant Formation, Cambrian, Nevada, USA, preserving three-dimensional gut tract, viewed from ventral side, PRI 68679. • A - view of entire specimen using standard photography, box indicates area enlarged in D. $\bullet$ B - explanatory diagram of A. $\bullet$ C - CT scan slice from anterior part of conch showing round cross-sectional profile of gut, interpreted as part of the nearly straight, longitudinally oriented rectum; for orientation, outline of shell margin has been added in red. $\bullet D-S E M$ view of gut tract in the boxed area of A showing central tube (rectum) surrounded by spiral intestine (broken in places); white arrow indicates a broken curving intestine. $\bullet \mathrm{E}$ - interpreted gut tract based on the arrangements of exposed gut remains shown in D. $\bullet \mathrm{F}$ - undetermined hyolithide from the Balang Formation, Cambrian, Guizhou, China, showing spiral intestine compacted in shale, viewed from ventral side, KW-110-17. Scale bars $=2 \mathrm{~mm}$ for A and B, $4 \mathrm{~mm}$ for $\mathrm{C}, 500 \mu \mathrm{m}$ for D and E, $1 \mathrm{~mm}$ for F. Abbreviations: An - anus, Ap - aperture, Co - conch, In - intestine, Li - ligula, Re - rectum.

the helens. In addition, muscle scars present along the interior of the conch in some species (Marek 1963, 1972) are likely to have facilitated extension and retraction of the helens. The proximal ends of the helens, upon retraction, would have lodged deep within the conch. Gut tracts of the new specimens are three-dimensionally preserved in part because of sediment fill, which lends support for the conclusion that these hyolithides were sediment-deposit or detritus feeders (see also Marek \& Yochelson 1976, Babcock \& Robison 1988, Butterfield \& Nicholas 1996).

\section{Evolutionary implications}

The evolutionary affinities of hyoliths have long been controversial and involve two leading hypotheses: an extinct phylum with a close relationship to sipunculan worms (e.g. Runnegar et al. 1975, Runnegar 1980, Pojeta 1997), or a class of mollusks (e.g. Marek \& Yochelson 1976, Malinky $\&$ Yochelson 2007). A molluskan affinity has been inferred in part by the presence and structure of aragonitic shell material, whereas a sipunculan affinity has been suggested 

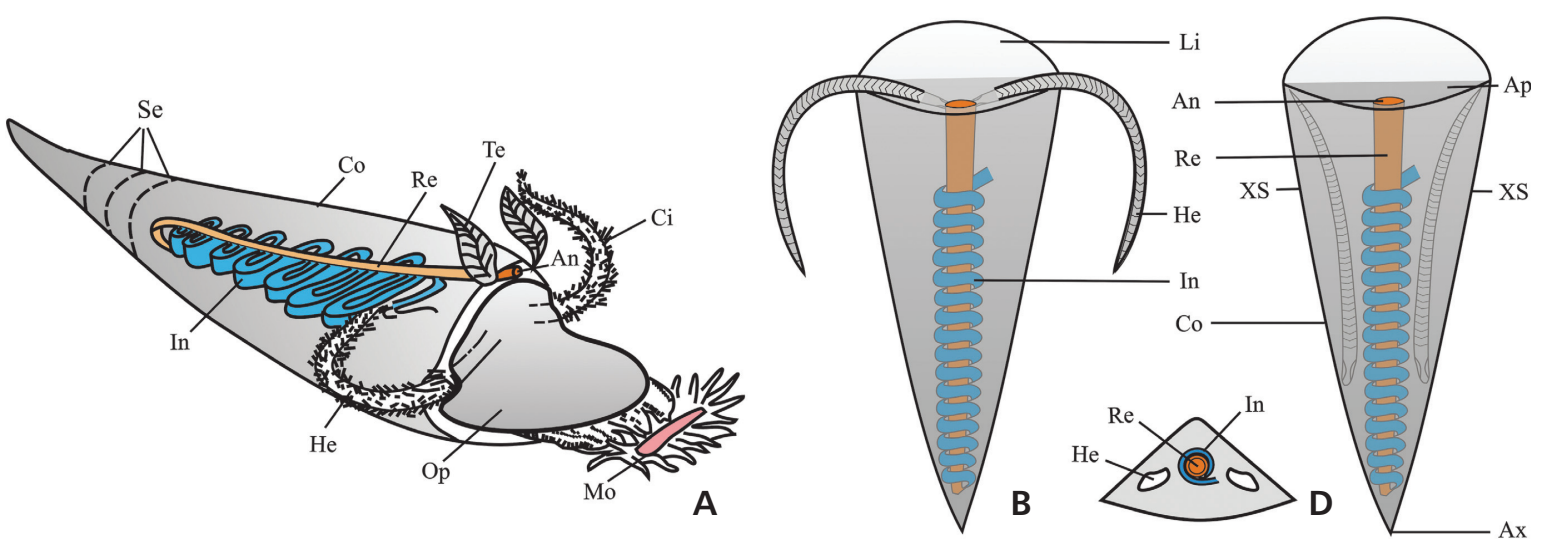

Figure 2. Reconstructions of hyolithides. $\bullet$ A - early hyolithide reconstruction based on orthothecide model (Missarzhevskiy 1989). B-D - new anatomical reconstructions of hyolithide based on new specimens; B, C - general body organization; B - dorsal view with helens extended; C - dorsal view with helens retracted; D - cross-section with helens retracted (compare with C). Abbreviations: An - anus, Ap - aperture, Ax - apex, Ci - cilium, Co - conch, $\mathrm{He}$ - helen, In - intestine, Li - ligula, Mo - mouth, Op - operculum, Re - rectum, $\mathrm{Se}$ - septum, Te - tentacle, XS - position of transverse cross-section in D.

largely by the gut configuration of orthothecides. Recently, Martí Mus et al. (2014) provided evidence that the basic developmental pattern of hyoliths shares similarities with that of some extant lophotrochozoans, especially annelids and mollusks. Other forms of evidence, such as hard-part evidence, have provided ambiguous evolutionary information. Calcium carbonate hard parts have evolved multiple times in the animal kingdom, and the relatively simple, modified cones could be construed as homoplasic (convergent) with a varied array of modified cones known among mollusks and even other animals.

In Fig. 3, we provide a tentative hypothesis for the evolutionary relationships of mollusks, hyoliths, and sipunculans based on what we now know, including the gut configuration of both orthothecide and hyolithide hyoliths. It is reasonable to presume that mollusks, hyoliths, and sipunculans all share a deeply rooted common ancestry (see Pojeta 1987). The relatively simple gut form in primitive mollusks may have appeared first as suggested by stratigraphic first appearances, and the more complicated gut forms of hyoliths and sipunculans would then be of later origination.

Mollusks, which appeared earlier in Earth history than either hyoliths or sipunculans, have what seems to be the most primitive form of digestive system among the groups considered (Fig. 3). The digestive tract of mollusks is usually a simple, irregularly curved tube (e.g. Purchon 1977, Brooker et al. 2014), which differs from the more complicated gut tracts of both hyoliths and sipunculans. The earliest fossil record of a possible mollusk is from Ediacaran Stage 4 (Fedonkin \& Waggoner 1997), and definite mollusks have been recorded from the Fortunian Stage of the Cambrian (e.g. Kouchinsky et al. 2012).

The fossil record of sipunculans, which lack hard parts, is scant and greatly underestimates the full evolutionary history of the group, as it depends largely on the finding of rare specimens in Fossil-Lagerstätten. Huang et al. (2004) described sipunculans with U-shaped guts from the Maotianshan Shale (Cambrian Stage 3) of Yunnan Province, China. Holocene sipunculans have simple U- or J-shaped digestive tracts in early ontogeny, which in adults are modified into U-shaped gut tracts that spirally wind around each other (e.g. Runnegar et al. 1975, Cutler 1994, Devaere et al. 2014). As such, they share similarities with the ontogenetic development of orthothecides (Devaere et al. 2014) and with adult hyolithides (Figs 1, 2B, C, 3).

Hyoliths, which have readily preservable hard parts, have an excellent fossil record, and stratigraphic first appearances of orthothecides and hyolithides (Fig. 3) provide support for the interpretation that orthothecides are the more primitive group. The earliest orthothecides are in the Fortunian Stage (earliest Cambrian; Li et al. 2007, Kouchinsky et al. 2012 and references in each), and the earliest hyolithides are known from Cambrian Stage 2 (Qian \& Xiao 1995, Li et al. 2007 and references in each).

The gut tract of the hyolithides shows both similarities with and differences from the gut tract of orthothecide hyoliths and sipunculans. Hyolithides have a U-shaped gut tract consisting of an intestine that spirals around a nearly straight rectum (Figs 1, 2B, C, 3; see also Babcock \& Robison 1988, Mao et al. 1992, Butterfield 2003). Orthothecides have a U-shaped gut consisting of a planar-folded (left-right looping), ventrally located intestine followed by a nearly straight dorsal rectum (Thoral 1935, Marek 1967, Runnegar et al. 1975, Meshkova \& Sysoyev 1981, Pojeta 1987, Kruse 1997, Horný 1998, Malinky 2003, Wilson \& Ratcliffe 2003, Valent \& Kraft 2009, Devaere et al. 2014). The intestine does not wind around the presumed rectum, as it does in hyolithides. The digestive system of sipunculans is a simple U- or J-shaped gut in early ontogeny that becomes modified to a U-shaped, spirally winding gut in adults (e.g. Runnegar et al. 1975, 
Figure 3. Proposed phylogenetic relationships of mollusks, orthothecides, hyolithides and sipunculans. Schematic figures modified after Brooker et al. (2014 [mollusk]), Devaere et al. (2014 [orthothecide]), Runnegar et al. (1975 [sipunculan]). Subdivision scheme of the Ediacaran system follows Narbonne et al. (2012) and Shu et al. (2014).

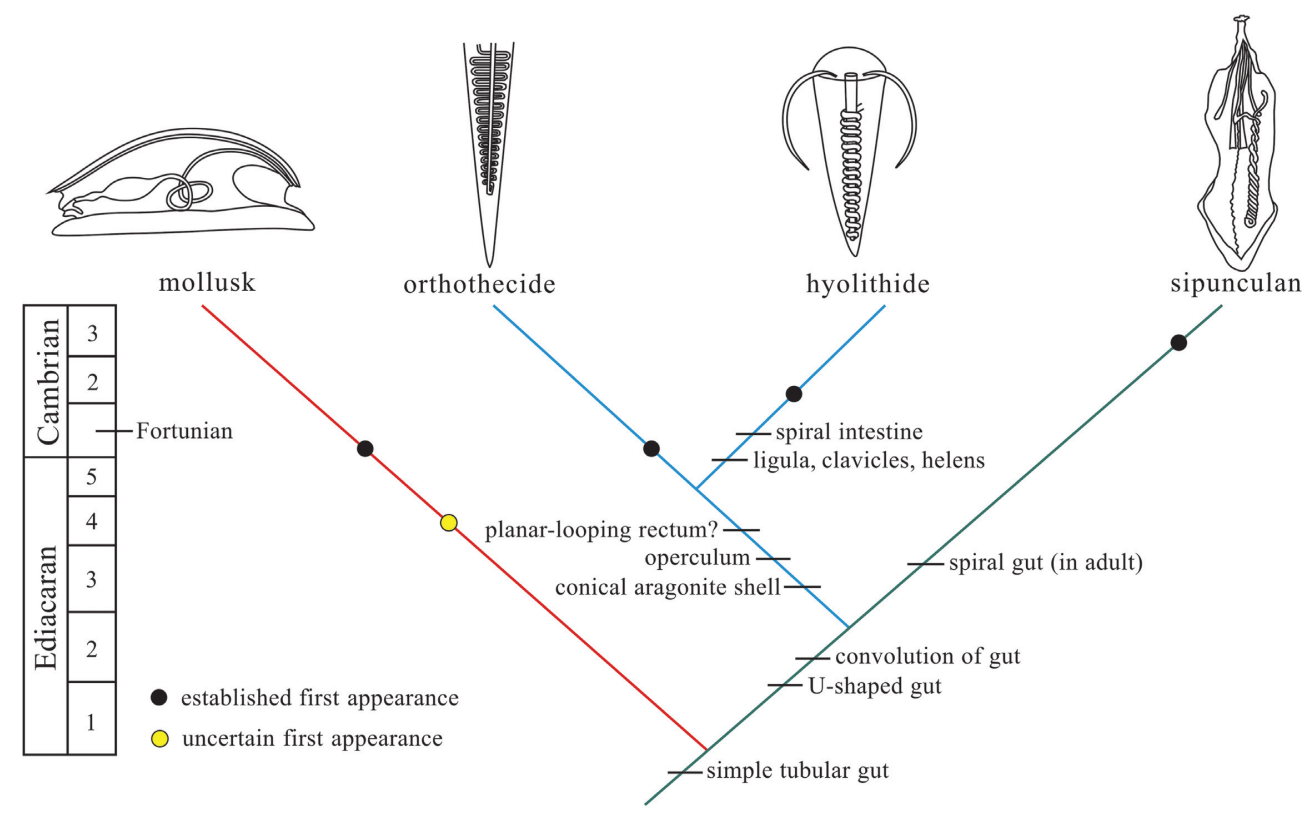

Culter 1994). Structural similarities in the gut tracts of sipunculans and hyoliths, including their ontogenetic development in sipunculans, have been used to infer a sister-group relationship between the two groups (e.g. Runnegar et al. 1975, Pojeta 1997, Devaere et al. 2014). If so, the tendency for convolution of the gut was probably present in the common ancestor of sipunculans and hyoliths (Fig. 3). Convolution, either by spiraling or looping, provides greater total surface area and volume than a simple tube for functions such as digestion. Because of its functional efficiency, a spiral is a common feature that has arisen homoplasically numerous times among animals (see Babcock 2005).

The conical aragonite shell of hyoliths, and the operculum equipped with cardinal processes are regarded as synapomorphies of the hyoliths (Fig. 3). Autapomorphous modifications of the shell in hyolithides include evolution of the ligula, clavicles on the operculum, and the paired helens (Fig. 3). The spiral intestine of hyolithides is most likely an autapomorphous condition. The point at which the planar-looping intestine present in orthothecides was derived is not known with certainty. It may have been either a synapomorphy that developed in early hyoliths or an autapomorphy that developed in orthothecides. Because the rectum is straight in both groups, it seems reasonable to interpret spiraling of the intestine around the rectum in hyolithides as a secondary condition compared to the looping of the intestine below the rectum known from orthothecides.

\section{Acknowledgments}

Material used in this study was collected in part by L.B. McCollum, M. McCollum, and F.A. Sundberg. J.A. Sheets pro- vided access to SEM facilities, and A.E. Cook provided access to CT scanning facilities. J. Kastigar assisted with CT scanning. M. Valent and an anonymous reviewer provided constructive and helpful comments that greatly improved the manuscript. N. Hughes edited the manuscript and provided additional constructive comments. This research was supported partly by grants from the Major State Basic Research Development Program of China (973 Program, No. 2013CB835002), the National Sciences Foundation of China (No. 41172005, No. 41330101), the Key Project of International Cooperation of Guizhou Science and Technology Department (Gui. Co. 2010-7001), the Science, Technology and Education Talents from Governor of Guizhou Province (Gui. Sp. 2011-37), Research Central of Paleontology of Guizhou (Gui. Sci. Z. [2014] 4003), Attracted Talent of Guizhou University (No. 2010021), and the China Scholarship Council.

\section{References}

BABCOCK, L.E. 2005. Asymmetry in the fossil record. European Review 13, 135-143. DOI 10.1017/S1062798705000712

BАвСоск, L.E. \& RoBison, R.A. 1988. Taxonomy and paleobiology of some Middle Cambrian Scenella (Cnidaria) and hyolithids (Mollusca) from western North America. University of Kansas Paleontological Contributions 121, 1-22.

Botting, J.P., Muir, L.A., JoRdan, N. \& Upton, C. 2015. An Ordovician variation on Burgess Shale-type biotas. Scientific Reports 5, 9947. DOI 10.1038/srep09947

Brooker, R.J., Widmaier, E., Graham, L. \& Stiling, P. 2014. Principles of Biology. 1072 pp. McGraw-Hill Science/Engineering/Math, New York.

ButTERFIELD, N.J. 2003. Exceptional fossil preservation and the Cambrian explosion. Integrative and Comparative Biology 43, 166-177. DOI 10.1093/icb/43.1.166

Butterfield, N.J. \& Nicholas, C.J. 1996. Burgess shale-type preservation of both non-mineralizing and 'shelly' Cambrian organisms from the Mackenzie Mountains, northwestern Canada. Journal of Palaeontology 70, 893-899. 
CutLer, E.B. 1994. The Sipuncula - their Systematics, Biology, and Evolution. 480 pp. Cornell University Press, Ithaca, New York.

Devaere, L., Clausen, S., Álvaro, J.J., Peel, J.S. \& Vachard, D. 2014. Terreneuvian orthothecid (Hyolitha) digestive tracts from northern Montagne Noire, France: taphonomic, ontogenetic and phylogenetic implications. PLoS ONE 9(2), 1-14. DOI 10.1371/journal.pone.0088583

DzIK, J. 1980. Ontogeny of Bactrotheca and related hyoliths. Geologiska Föreningeni Stockholm Förhandlingar 102, 223-233. DOI 10.1080/11035898009455162

English, A.M. \& BАвСоск, L.E. 2010. Census of the Indian Springs Lagerstätte, Poleta Formation (Cambrian), western Nevada, USA. Palaeogeography, Palaeoclimatology, Palaeoecology 295, 236-244.

DOI 10.1016/j.palaeo.2010.05.041

Fedonkin, M.A. \& Waggoner, B.M. 1997. The late Precambrian fossil Kimberella is a mollusk-like bilaterian organism. $\mathrm{Na}$ ture 388, 868-871. DOI 10.1038/42242

HoRnÝ, R.J. 1998. Lower Ordovician Nephrotheca sarkaensis (Orthothecida, Hyolitha) with fossilized intestinal contents in situ (Šárka Formation, Bohemia). Journal of the National Museum (Prague), Natural History Series 167, 95-98.

Huang, D.Y., Chen, J.Y., Vannier, J. \& Saiz Salinas, J.I. 2004. Early Cambrian sipunculan worms from Southwest China. Proceedings of the Royal Society (London) B 271, 1671-1676. DOI 10.1098/rspb.2004.2774

Kouchinsky, A., Bengtson, S., Runnegar, B., Skovsted, C., Steiner, M. \& Vendrasco, M. 2012. Chronology of early Cambrian biomineralization. Geological Magazine 149, 221-251. DOI 10.1017/S0016756811000720

KRuSE, P.D. 1997. Hyolith guts in the Cambrian of northern Australia - turning hyolithomorphs upside down. Lethaia 29, 213-217. DOI 10.1111/j.1502-3931.1996.tb01651.x

Li, G.X., Steiner, M., Zhu, X.J., YANG, A.H., WANG, H.F. \& ERDTMAnN, B.D. 2007. Early Cambrian metazoan fossil record of South China: generic diversity and radiation patterns. Palaeogeography, Palaeoclimatology, Palaeoecology 254, 229-249. DOI 10.1016/j.palaeo.2007.03.017

MaLinKy, J.M. 2003. Ordovician and Silurian hyoliths and gastropods reassigned from the Hyolitha from the Girvan district, Scotland. Journal of Paleontology 77, 625-645. DOI 10.1666/0022-3360(2003)077<0625:OASHAG>2.0.CO;2

MalinKy, J.M. \& Yochelson, E.L. 2007. On the systematic position of the Hyolitha (kingdom Animalia). Memoirs of the Association of Australasian Palaeontologists 34, 521-536.

MaO, J.R., ZhaO, Y.L., Yu, P. \& Qian, Y. 1992. Some middle Cambrian hyolithids from Taijiang, Guizhou. Acta Micropalaeontologica Sinica 9, 257-265. [in Chinese with English abstract]

MareK, L. 1963. New knowledge on the morphology of Hyolithes. Sborník geologických věd, Paleontologie 1, 53-73.

MAREK, L. 1966. New hyolithid genera from the Ordovician of Bohemia. Časopis Národního muzea, Oddíl př́rodovědný 135, 89-92.

MAReK, L. 1967. The class Hyolitha in the Caradoc of Bohemia. Sborník geologických věd 9, 51-112.

MareK, L. 1972. Maxilites gen. n. ze středního kambria (Hyolitha). Paleozoologie 141, 69-72.

Marek, L., Parsley, R.L. \& Galle, A. 1997. Functional morphology of hyoliths based on flume studies. Věstník Českého geologického ústavu 72, 351-358.
Marek, L. \& Yochelson, E.L. 1976. Aspects of the biology of Hyolitha (Mollusca). Lethaia 9, 65-82.

DOI 10.1111/j.1502-3931.1976.tb00952.x

Martí Mus, M. \& Bergström, J. 2005. The morphology of hyolithids and its functional implications. Palaeontology 48, 1139-1167. DOI 10.1111/j.1475-4983.2005.00511.x

Martí Mus, M. \& BergströM, J. 2007. Skeletal microstructure of helens, lateral spines of hyolithids. Palaeontology 50, 1231-1243. DOI 10.1111/j.1475-4983.2007.00700.x

Martí Mus, M., Jeppsson, L. \& MalinKy, J.M. 2014. A complete reconstruction of the hyolithid skeleton. Journal of Paleontology $88,160-170$. DOI 10.1666/13-038

Meshrova, N.P. \& Sysoyev, V.A. 1981. A find of casts of the digestive apparatus of Lower Cambrian hyoliths, 82-85. In SoKOLOv, B.S. (ed.) Phanerozoic Problematica. Institute of Geology and Geophysics, USSR Academy of Science, Novosibirsk.

MissaRZHEvskiY, B.B. 1989. Drevniyshie skeletne okamenelosti i stratigrafiya poranitsnikh tolsh dokembriya i kembriya. Trudy GIN AN SSSR 443, 1-238. [in Russian]

Narbonne, G.M., Xiao, S.H. \& Shields, G.A. 2012. The Ediacaran Period, 413-435. In Gradstein, F.M., OGG, J.G., Schmitz, M.D. \& OGg, G.M. (eds) The Geologic Time Scale 2012. Elsevier, Amsterdam.

PojetA, J., JR. 1987. Phylum Hyolitha, 416-444. In BoArdman, R.S., Cheetham, A.H. \& Rowell, A.J. (eds) Fossil Invertebrates. Blackwell, Palo Alto, California.

Purchon, R.D. 1977. The Biology of the Mollusca (second edition). 560 pp. Pergamon Press, Oxford.

Qian, Y. \& XIAO, L.G. 1995. Hyolitha. 262 pp. Science Press, Beijing. [in Chinese]

Robison, R.A., BAвсоск, L.E. \& Gunther, V.G. 2015. Exceptional Cambrian fossils from Utah: a window into the Age of Trilobites. Utah Geological Survey Miscellaneous Publication 15-1, 1-97.

RunNEGAR, B. 1980. Hyolitha: status of the phylum. Lethaia 13, 21-25. DOI 10.1111/j.1502-3931.1980.tb01025.x

Runnegar, B., Pojeta, J., Morris, N.J., Taylor, J.D., Taylor, M.E. \& McClung, G.1975. Biology of Hyolitha. Lethaia 8, 181-191. DOI 10.1111/j.1502-3931.1975.tb01311.x

Shu, D.G., Isozaki, Y., Zhang, X.L., Han, J. \& Maruyama, S. 2014. Birth and early evolution of metazoans. Gondwana Research 25, 884-895. DOI 10.1016/j.gr.2013.09.001

Skovsted, C.B., Peel, J. \& Atkins, C.J. 2004. The problematic fossil Triplicatella from the early Cambrian of Greenland, Canada, and Siberia. Canadian Journal of Earth Sciences 41, 1273-1283. DOI 10.1139/e04-066

Skovsted, C.B., Topper, T.P., Betts, M.J. \& Brock, G.A. 2014. Associated conchs and opercula of Triplicatella disdoma (Hyolitha) from the early Cambrian of South Australia. Alcheringa 38, 148-153. DOI 10.1080/03115518.2014.843381

ThORAL, M. 1935. Contribution à l'étude paléontologique de l'Ordovicien Inférieur de la Montagne Noire et revision sommaire de la faune cambrienne de la Montagne Noire. 362 pp. Imprimerie de la Charité, Montpellier.

VALENT, M. \& KRAFT, P. 2009. Fillings of hyolithid guts from the Middle Ordovician of the Prague Basin (Czech Republic), 103-104. NAPC Cincinnati, Cincinnati, Ohio, USA.

Wilson, L. \& RAtCliffe, P. 2003. Three dimensional phosphatic preservation of hyolith guts from the Montagne Noire: insights into hyolith ontogeny and phylogeny. Palaeontological Association Newsletter 54, 186. 